Journal of Teacher Education for Sustainability, vol. 15, no. 2, pp. 52-66, 2013

\title{
COMPETITIVENESS AND QUALITY OF HIGHER EDUCATION: GRADUATES' EVALUATION
}

\author{
Veronika Bikse \\ Liepaja University, Latvia,
}

Baiba Rivža and Ieva Brence

Latvian Academy of Sciences, Latvia

\begin{abstract}
The aim of the paper is to find the competitiveness of Latvian university graduates in Latvia and the European Union labour market concerning aspects of entrepreneurship education. To achieve the purpose of this study to determine the competitive and qualitative levels of Latvian universities and necessary improvements that need to be made, a survey of 4,909 graduates (from the years 2006-2011) representing six Latvia universities was performed between November-December, 2011. Results indicate that, in general, the graduates consider themselves competitive in the Latvian labour market. The graduates have positive opinions concerning the quality of theoretical knowledge as well as the abilities to present information and to evaluate, analyse and systematise it. At the same time, there are serious improvements that are necessary in regard to entrepreneurship education and to increase the competitiveness of Latvian universities, which can be done by improving the quality of the study process, the content of courses, teaching (learning) methods and the attitudes of academic staff to better motive students to develop their skills emphasising the practical side of the study process.
\end{abstract}

Key words: higher education, competitiveness, quality, entrepreneurship education, entrepreneurial skills and competences

\section{Introduction}

Nowadays the most important precondition of competitiveness of higher education is the development of a competent individual. This places new and much higher demands for the development and education of human capital - implementing the development of competence-based education. Consequently, the implementation of competence-based education represents a new perspective on the formation of educational content, which presently includes the development of the eigth key competences, determined by the European Commission (EC, 2002, 2012b). One important competency is to develop entrepreneurial competencies, which are to be developed within an education process by everyone starting from early childhood and continuing throughout life. 
Encouraging the entrepreneurial spirit in young people is a precondition to achieving progress - at least in the longer term - in the innovation, employment, growth and competitiveness in any given national environment (EC, 2006). Therefore entrepreneurship in education and training is recognised as a central element in the European Union (EU) entrepreneurship policy.

The term entrepreneurship education is often narrowly defined to either running a business or being an employer or self-employed. Entrepreneurship education is much wider than just training persons on how to start businesses. According to the EC (2008), entrepreneurship education may include following elements: 1) developing personal qualities, attitudes and skills that form the basis of an entrepreneurial mindset and behaviour (creativity, making decisions, communication, responsibility, risk taking, independence, self-confidence, leadership, team spirit, etc.);2) providing specific business skills and knowledge concerning what must be done to establish a new enterprise and how to be successful in developing an idea into a practical, goal-oriented enterprise; 3 ) working on concrete enterprise projects and activities; 4) raising students' awareness of self-employment and entrepreneurship as a career options (become not only an employee, but also an entrepreneur). Together these main elements will give young people entrepreneurial competence.

As for higher education, in the EC (2008) project "Entrepreneurship in higher education, especially in non-business studies", it is stated that the aspects of developing entrepreneurial competencies should be integrated as an important part of the curriculum, spread across different subjects, and require or encourage students to take entrepreneurship courses.

Reacting to the new conditions, the Latvian government has already passed the regulations (Latvijas Republikas Ministru kabinets [the Cabinet of Ministers of the Republic of Latvia], 2001) to make a course obligatory to develop basic social, communicative and organisation skills focused on developing professional competences for entrepreneurship. The module should have 6 credits (9 ECTS) and be included in all bachelor degree programmes. The module mostly includes methods of competence training, business games, coaching, etc.

Today, entrepreneurship education has become an important aspect for measuring higher education competitiveness and quality, and study programmes should be adjusted to involve components of entrepreneurship education.

The most important problems concerning entrepreneurship education in Latvia concern the prevailing traditional approach towards this type of education. Very often, education systems concentrate on transmitting professional or vocational skills, leaving the personal qualities and skills (competences) more or less to chance. However, these can be developed and encouraged in parallel throughout vocational skill instruction. Research shows that, where this is done, the effectiveness of teaching increases (Bikse \& Riemere, 2013).

The aim of this work is to determine the competitiveness of Latvian university graduates in the Latvian and the EU labour market, inter alia concerning aspects of entrepreneurship education.

The questions addressed in this paper are the following: What does competitive and qualitative education mean? and What are the main problems identified in Latvia, inter alia in entrepreneurship education? 


\section{Research methodology and participants}

To reach the aim, theoretical concepts were studied and the EC documents (EC, 2012a, $2012 \mathrm{~b}$ ) analysed, among others for the theoretical concepts of competitive, sustainable and qualitative education. To get a deeper insight into the problem, a survey was undertaken in all Latvian universities and an analysis of the results has been prepared. The survey was performed during the period November - December 2011, and 4.909 graduates (from 2006 to 2011) representing all Latvian universities were surveyed via the internet (WAPI). In total, there were 17.160 potential respondents who were originally invited to take part in the survey, by using the email addresses made available in the university databases. Of this potential response, 6.500 completed questionnaires were returned. Among the other replies, 332 questionnaires were considered as inappropriate for the target group, and 1.529 questionnaires had not been filled out as prescribed. Thus, 4,909 remaining questionnaire responses were considered as suitable for the purposes of this study. The survey was anlysed and the data processed by the SIA "Marketing and Public Opinion Research Centre" (SKDS Ltd) in November - December 2011, within the framework of the project "Universities Investment in the Latvian Economy" (LUA (Latvijas Universitāšu asociācijas) projekts "Universitāšu ieguldījums Latvijas tautsaimniecībā" [Project of universities investment in Latvian economy (UILE)], 2012).

Most of the respondents were women $(70.4 \%) .81 .5 \%$ of the respondents were aged between $18-34.46 .3 \%$ of them had a bachelor's degree, $39.7 \%$ - a master's degree and $2 \%$ - a doctoral degree. Other participants had a first or second level professional higher education.

The distribution of the persons surveyed (\%) was the following - the University of Latvia $-34.1 \%$, Riga Technical University $-28.8 \%$, Latvia University of Agriculture $13.4 \%$, Rìga Stradiņ̌̌ University - 4.3\%, Daugavpils University - 8.3\%, Liepāja University $11 \%$. Most of the respondents ( $89 \%$ ) had studied in one university only. $10 \%$ of the respondents had studied in two higher education institutions, and $1 \%$ - in three or four higher education institutions. The largest number of respondents who had studied in several higher education institutions were the graduates from Rīga Stradiňš University $(19 \%)$.

With regard to the educational thematic groups/fields in which the graduates had studied, the proportional breakdown of the graduates was as follows: social sciences, commercial sciences and law $-37.3 \%$; engineering sciences, production and construction $16.6 \%$, natural sciences, mathematics and information technologies $-14.0 \%$, teacher education and educational sciences $-9.7 \%$, humanitarian sciences and the arts $-9.5 \%$, healthcare and social welfare $-6.2 \%$, services $-4.7 \%$ and agriculture $-2.0 \%$.

Taking into account the large number of aspects related to entrepreneurship education competitiveness and quality, in this paper, the authors will focus on the following components - higher education graduates' opinions of the skills gained during their studies and their opinions regarding higher education competitiveness.

\section{Employability status of the respondents}

A part of the survey was dedicated to finding the employment status of graduates. When characterising employment in the first year after graduating from university, $61.8 \%$ of the graduates noted that they continued to work in the same working place where they worked during their studies (inter alia $49.3 \%$ of the graduates with a bachelor's degree, $70.9 \%$ - with a masters' degree and $86.2 \%$ - with a doctoral degree), $29 \%$ of the res- 
pondents continued their studies, $18 \%$ - became employees (found a new job) and 10\% were searching for a job, but couldn't find it (inter alia $14 \%$ of the graduates held a bachelor's degree, $7.7 \%$ - held a masters' degree and 3.2\% - held a doctoral degree).

The survey proved that, out of 4.909 respondents, many were employed as employees in the private sector $(41.09 \%)$ and in the public sector or municipalities $(31.3 \%) .212$ out of the respondents or 5\% were employers (entrepreneurs). 258 of the respondents or $6.1 \%$ had gained the status of self-employed, inter alia they became self-employed after graduating from university or started their own entrepreneurship. In comparison with the survey results of the 2002-2005 graduates, "5\% from them were employers and only 3\% were self-employed" (Professional activities of graduates of higher and vocational education institutions after graduation, 2007, p. 5).

By characterising the economy branch that has to correspond to the working place of the respondents, $20.4 \%$ of them were employed in production spheres (production, agriculture, construction, electro-energy, etc.), $19.5 \%$ - in education, $9.1 \%$ - in state institutions, $7.9 \%$ - in health and social care, and others were employed in different services sectors.

A considerable number of graduates were employed in management positions $38 \%$ out of the respondents, inter alia 256 of $5.5 \%$ - at a higher level management, 975 or $20.3 \%$ - at a medium level management, 587 or $12.2 \%$ - at a lower level management. The biggest proportion of the graduates from agriculture $(37.9 \%)$ and services were those who held the higher and medium level management positions.

Only $14.4 \%$ of the graduates were planning to start their own entrepreneurship within the next three years.

The main advantages that motivate the respondents to gain a status of the selfemployed is to act independently and to realise his/her potential to full extent, by performing the job that is interesting. At the same time, these respondents that prefer being employees, consider a good job and regular incomes as the main advantage. Besides, they consider a good salary in the state administration to be an important asset.

The main obstacles for starting entrepreneurship among graduates are financial problems $(46.2 \%)$ as well as lack of competencies and skills that are necessary for forming their own enterprise $(31.8 \%)$. Many of the respondents consider that income is not guaranteed then $(27.5 \%)$ and they are not willing to take risk $(27.6 \%)$, besides there are complicated administrative procedures in the country $(25.2 \%)$, and there are no ideas on how to start entrepreneurship (23.5\%) as well as lack of susceptibility is indicated $(19.4 \%)$.

Thus, it may be concluded that most of the graduates are employed as higher or medium level managers. Nevertheless, most of the recent graduates are employees, and a number of employers (entrepreneurs) among them is comparatively low. Even more, most of the respondents are not willing to establish their own enterprise in future, to become self-employed.

\section{Research findings}

\section{Higher education quality and competitiveness: Theoretical aspects}

Education has become an important tool in the whole world for ensuring economic and social progress. It is the basis of increasing of intellectual and education potential. Invest- 
ments in education and self-development create added value for a person, accumulate additional income in the future and is one of the main factors for ensuring competitiveness in the labour market. Importance of education has changed considerably in the $21^{\text {st }}$ century, since adjustment to internationalisation of the world economy, changes in science and information technologies have to be ensured. Education quality and challenges concerning the necessity to increase competitiveness has become a question of importance in the whole world, inter alia in the EU.

The internationalisation aspect shouldn't be distinguished from the aspect of quality. Taking into account internationalisation processes, education quality has become an international term, since it is measured internationally and universities are compared within each other all over the world.

There is also a growing debate on what qualitative education means, as Federkeil (2008) states.

The EC (2011) states that higher education enhances individual potential and should equip graduates with the knowledge and core transferable competences they need to succeed in high-skill occupations (EC, 2011). The use of skills and growth projections and graduates' employment data (including tracking graduates' employment outcomes) should be encouraged in course designs, delivery and evaluation, adapting quality assurance and funding mechanisms to reward success in equipping students for the labour market (EC, 2011). Universities, public administrations and enterprises must ensure a strong commitment on the issue of employability. Apart from higher education quality, different research has been performed studying the opinions of students and graduates concerning their studies. For instance, a study of Gendjova and Kamusheva (2012) seeks a relationship between learning at the Faculty of Chemistry at Sofia University and the career development of the graduates. For this purpose, an online-based survey of 100 students was conducted. The students graduated with a bachelor's or master's degrees over the past five years (2006-2010). Based on their experience, the graduates determined the generic skills and competences, which they believed to be the most important for their career and the extent to which these competences are developed in the university (Gendjova \& Kamusheva, 2012).

As regards to education, professionalisation will become central both at the bachelor's and master's levels. To deliver the appropriate teaching, curricula must be codesigned with industries, industry actors must be involved in teaching, and academic careers should be reshaped to reward the teaching involvement (Poisson, 2012). Business leaders also recognise the essential contributions that universities make in providing their companies and their regional economies with a competitive advantage through highly skilled workers, advanced technology, unparalleled knowledge and practical know-how (Bokhari, 2010). Employment of postgraduates is the permanent theme of higher education in every country and higher education institutes and professors should pay attention to postgraduates' employment competitiveness (Qi, 2011).

On the one side, there is still a big debate on what competitive education means. Many scientific articles state that higher education must be competitive (Daun \& Arjmand, 2005; Viederyte, 2009; Zernov, 2009; Adcroft, Teckman, \& Willis, 2010; Fadeeva \& Galkute, 2012). At the same time, the question still remains open: What does competitive higher education mean? The aspect that is often linked with competitive education is sustainability (Dawson, Burnett, \& O’Donohue, 2006; Dobson, Quilley, \& Young, 2010; Krivova \& Myachin, 2011; Fadeeva \& Galkute, 2012). 
Summarising the definitions characterising higher education sustainability, the authors suggest that sustainability involves several aspects, for instance, reaction to quantitative and qualitative changes in the labour market and regular measurement of higher education quality, inter alia by organising regular surveys of higher education institutions' graduates and by analysing the survey results.

With special requirements in education at global level, educational institutions adopt various approaches, methods, innovations to answer the rising demands of competitiveness and efficiency for learners of all categories and ages (Acqui, 2012) that goes hand in hand with reaction to quantitative and qualitative changes in the labour market. As well, the opinions of students and graduates are usually included in the higher education institution measurements for higher education competitiveness. At the same time, the authors hold the view that this aspect is not evaluated as significantly as it should be. Thus the next chapter is devoted to the analysis of Latvian graduates' opinions on the quality of higher education.

\section{Graduates' evaluation on the acquisition of necessary knowledge and skills, while studying at universities}

The theoretical part of the paper stresses the necessity to ensure quality of education. Thus the graduates evaluated knowledge and skills gained during their studies, and provided their attitude towards different statements related to higher education (Project of Universities Investment in Latvian Economy [UILE], 2012).

First, the graduates' opinion on knowledge and skills gained while studying at university is reflected. The ranking of graduates of knowledge and skills acquired at the highest level is the following: (percentage of graduates who assessed these skills in the scale - maximum $100 \%$ ):

- a possibility to gain theoretical knowledge in the chosen level, ability to work with information, to evaluate analyses and systematise it $(62.6 \%)$;

- skills gained for working in a team $(54.1 \%)$;

- skills to plan, organise and manage their own work $(53.7 \%)$;

- skills to take decisions, relying on the previous information analysis (52.4\%);

- skills to present information to public $(51.2 \%)$.

The following possibilities are evaluated as being at a medium and a low level:

- discuss to public and support the opinion (48.9\%);

- provide innovative solutions for problems of different difficulty level (51.4\%);

- apply theoretical knowledge to practical work $(52.2 \%)$;

- gain research skills $(53.2 \%)$;

- gain skills in preparing documents and reports (52.9\%);

- learn terms in the field of academic study in foreign languages (50.9\%).

The following skills were evaluated as being acquired at a low and a very low level:

- work with specific computer programmes of the branch $(24 \%)$;

- gain skills for starting entrepreneurship (31.5\%).

The graduates' evaluation concerning the level of knowledge acquisition and skills development at the university leads to a conclusion that possibilities to gain theoretical knowledge received the highest evaluation. The same regards to the abilities to present 
information and to evaluate, analyse and systematise it. The basis of theoretical knowledge is very important, since the theory provides analytical instruments that are necessary for understanding the meaning of concrete facts and analysing them, for helping to take purposeful decisions on personal and socio-economic questions. Therefore the necessity to gain theoretical knowledge is obvious. At the same time, the knowledge should be applied to practice. The research proves that many of the skills necessary nowadays are acquired at the university at the medium or even low level. Too little attention is paid towards a practical side of the study, for instance, the possibility for students to work in projects, research, to find solutions, to use information technologies, to develop the necessary skills corresponding to the present labour market requirements.

One should not exclude that graduates consider that entrepreneurship education is implemented insufficiently at universities. The graduates' answers show that the knowledge in entrepreneurship has received the lowest level. 1,340 or $27.3 \%$ of the respondents have not learned the skills at all, 1,549 or $31.5 \%$ - have learned the skills at a low or very low level, and 1,328 or $27.1 \%$ - have learned these skills at a medium level. Only 623 or $12.7 \%$ of the respondents have learned the skills at a high and very high level. The analysis performed on education thematic groups proves that the biggest part of the respondents who have had no possibilities to learn skills in entrepreneurship while studying at university were from the academic field of humanities and art $(50.6 \%)$. More detailed information is provided in Table 1.

Table 1. Graduates' evaluation of the level of acquired skills in entrepreneurship education in the frames of thematic groups*

\begin{tabular}{lcccccc}
\hline \multicolumn{1}{c}{ Thematic group } & $\begin{array}{c}\text { Didn't } \\
\text { learn } \\
\text { \% }\end{array}$ & $\begin{array}{c}\text { At a very } \\
\text { low level } \\
\%\end{array}$ & $\begin{array}{c}\text { At a low } \\
\text { level } \\
\%\end{array}$ & $\begin{array}{c}\text { At a me- } \\
\text { dium level } \\
\%\end{array}$ & $\begin{array}{c}\text { At a high } \\
\text { level } \\
\%\end{array}$ & $\begin{array}{c}\text { At a very } \\
\text { high level } \\
\%\end{array}$ \\
\hline Education & 33.9 & 8.6 & 19.9 & 25.5 & 9.2 & 1.9 \\
\hline $\begin{array}{l}\text { Humanitarian sciences } \\
\text { and art }\end{array}$ & 50.6 & 5.8 & 12.6 & 17.3 & 5.6 & 1.7 \\
\hline $\begin{array}{l}\text { Social sciences, com- } \\
\text { mercial sciences and } \\
\text { law }\end{array}$ & 21.8 & 8.1 & 20.2 & 31.6 & 14.4 & 2.3 \\
\hline $\begin{array}{l}\text { Natural sciences, } \\
\text { mathematics and infor- } \\
\text { mation technologies }\end{array}$ & 32.7 & 14.7 & 26.1 & 17.9 & 5.7 & 1.7 \\
\hline $\begin{array}{l}\text { Engineering sciences, } \\
\text { production and con- } \\
\text { struction }\end{array}$ & 19.6 & 16.9 & 23.9 & 26.8 & 8.8 & 2.0 \\
\hline Agriculture & 4.1 & 4.1 & 32.0 & 39.2 & 14.4 & 6.2 \\
\hline $\begin{array}{l}\text { Health care and social } \\
\text { welfare }\end{array}$ & 27.2 & 8.9 & 24.8 & 28.5 & 7.9 & 1.0 \\
\hline Services & 20.3 & 6.9 & 18.5 & 34.5 & 15.5 & 3.4 \\
\hline Total & 27.3 & 10.2 & 21.3 & 27.1 & 10.6 & 2.1 \\
\hline
\end{tabular}

* Just one response is given in each row. The total response of $100 \%$ does not apply because some of respondents did not provide an answer to this question. 
Table 1 reflects that not only the graduates from the academic field of humanities and art, but also graduates from the thematic group of education (almost one third) didn't learn skills for starting entrepreneurship, and others have learned the skills at a very low level $(28.5 \%)$ and a medium level $(25.5 \%)$. Only $11.1 \%$ have learned the skills sufficiently. Thus future teachers, while studying at university, were not able to learn knowledge and skills necessary for integrating components into study courses for developing entrepreneurial abilities for pupils to the full extent. It means that, after graduating from university, the young teachers are still limited in their skills to ensure a new type of learning. In the authors' opinion, the evaluation could be better among the education thematic group of social sciences, commercial sciences and law respondents, since there is a number of courses in the study programmes of economics and management that stimulate entrepreneurship development. Nevertheless, $50.1 \%$ of the respondents note that they have not gained any skills in entrepreneurship education or have learned the skills at a low or very low level. It testifies that the EC $(2008,2012)$ guidelines and the regulations of the Cabinet of Ministers of the Republic of Latvia (Latvijas Republikas Ministru kabinets [the Cabinet of Ministers of the Republic of Latvia], 2001) on the necessity for all young persons to develop entrepreneurial skills are not followed completely.

The opinion of the respondents regarding the higher education in general is included. By analysing the answers to a number of statements, the following statements have received the highest evaluation: the education gained has prepared me for continuing education $190 \%$ out of the respondents agree to the statement to the fullest extent or note that they rather agree), the level of education gained corresponds to my personal investments (in terms of time and efforts) (84\% out of the respondents agree to the statement to the fullest extent or note that they rather agree) and the education gained has provided sufficient investments for development of my skills (83\% out of the respondents agree to the statement to the fullest extent or note that they rather agree). More detailed information is included in Figure 1.

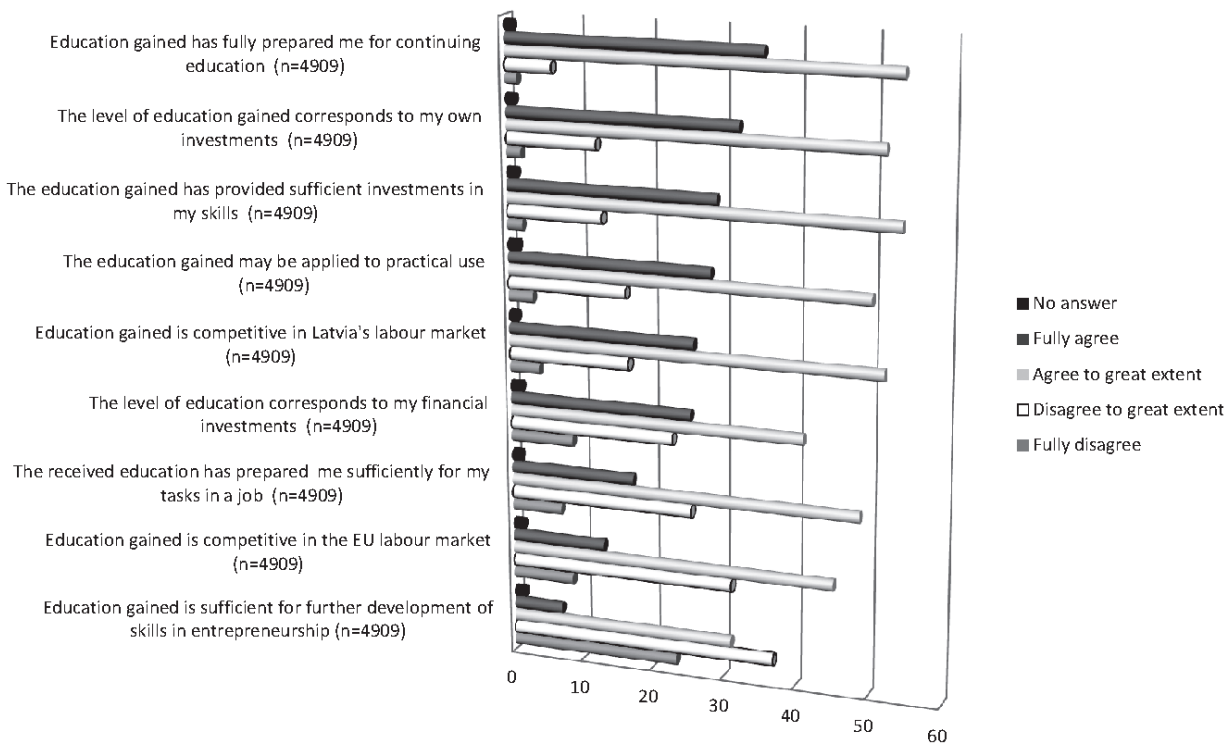

Figure 1. Graduates' evaluation of higher education in general 
In general, the students' evaluation is above the average, except for the evaluation universities investments in entrepreneurial skills development, preparation of specialists for development of their enterprise in future. Negative answers were provided only by $60.5 \%$ of the surveyed respondents. Only $6.9 \%$ out of the graduates surveyed were fully satisfied. Comparatively low was the evaluation for the statement whether the education gained in competitive in the EU labour market. The respondents' evaluation concerning the statement is reflected in Table 2.

Table 2. Respondents' evaluation of the statement "Education is competitive in Latvia's and the EU labour market"*

\begin{tabular}{|c|c|c|c|c|}
\hline \multirow[t]{2}{*}{ Thematic group } & \multicolumn{2}{|c|}{$\begin{array}{c}\text { Competitive in Latvia's } \\
\text { labour market }\end{array}$} & \multicolumn{2}{|c|}{$\begin{array}{l}\text { Competitive in the EU } \\
\text { labour market }\end{array}$} \\
\hline & $\begin{array}{c}\text { don't agree } \\
\% \\
\end{array}$ & $\begin{array}{l}\text { agree } \\
\%\end{array}$ & $\begin{array}{c}\text { don't agree } \\
\% \\
\end{array}$ & $\begin{array}{l}\text { agree } \\
\%\end{array}$ \\
\hline 1 Education & 19.9 & 79.7 & 41.2 & 57.3 \\
\hline 2 Humanitarian sciences and art & 38.5 & 61.1 & 47.4 & 51.7 \\
\hline $\begin{array}{l}3 \text { Social sciences, commercial } \\
\text { sciences and law }\end{array}$ & 23.2 & 75.7 & 46.9 & 51.6 \\
\hline $\begin{array}{l}4 \text { Natural sciences, mathematics } \\
\text { and information technologies }\end{array}$ & 13.8 & 85.0 & 28.1 & 70.4 \\
\hline $\begin{array}{l}5 \text { Engineering sciences, production } \\
\text { and construction }\end{array}$ & 16.9 & 81.4 & 35.9 & 62.4 \\
\hline 6 Agriculture & 15.5 & 84.5 & 35.1 & 64.9 \\
\hline 7 Health care and social welfare & 15.6 & 82.1 & 20.2 & 76.8 \\
\hline 8 Services & 18.5 & 81.0 & 40.5 & 58.6 \\
\hline 9 Total & 21.1 & 77.8 & 39.8 & 58.7 \\
\hline
\end{tabular}

* Just one response is given in each row. The total response of $100 \%$ does not apply because some of respondents did not provide an answer to this question.

447 respondents taking part in the survey had worked or are working abroad. When comparing the data of Table 2 and Figure 2, there is a correlation between evaluation of competitiveness in the EU labour market and the employment performed abroad compliance towards the speciality gained. The statements that the education gained is competitive in the EU labour market have been evaluated at the highest extent by the respondents having studied in health care and social welfare and natural sciences, mathematics and information technologies. Most of the graduates work in accordance with their speciality abroad.

The respondents were requested to indicate whether the current (or the last job, in case the respondent is not working at present) is related to the speciality gained (Figure 3). 


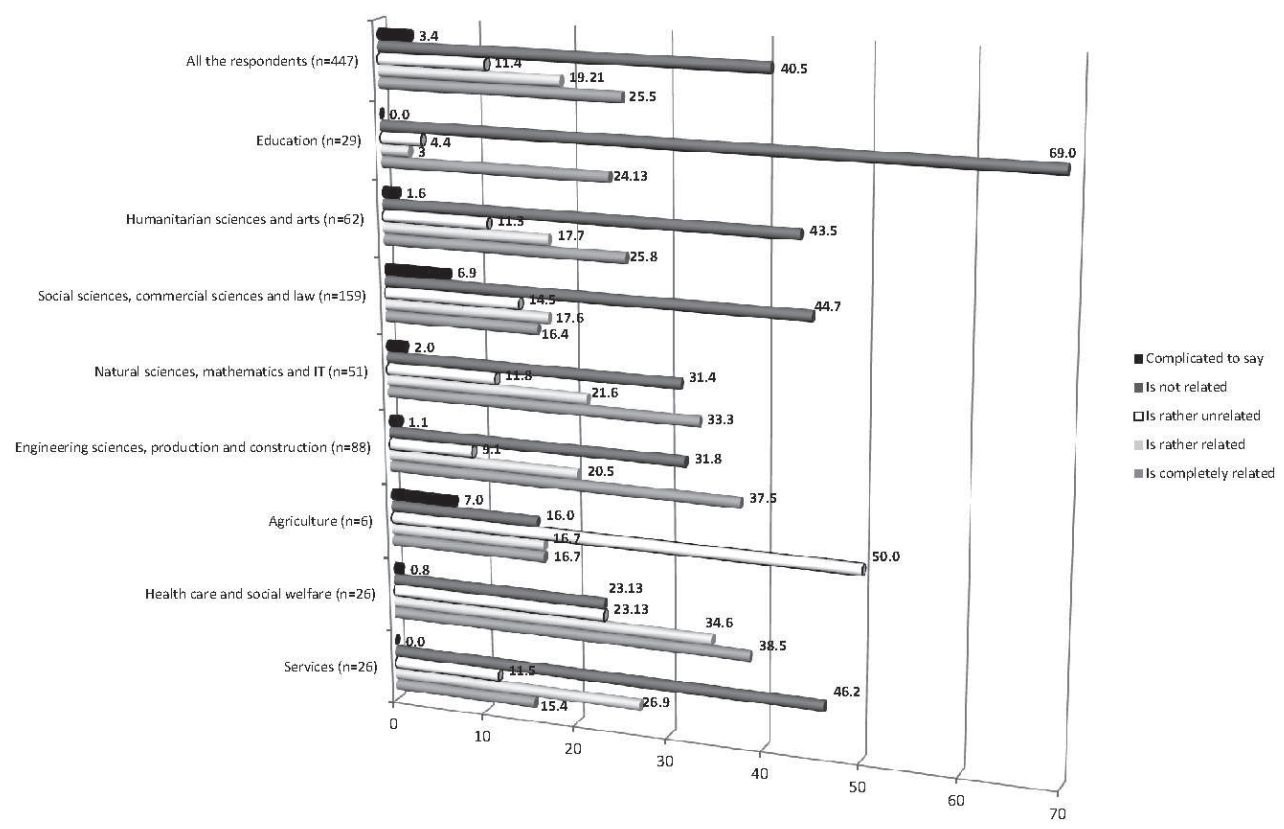

Figure 2. Graduates' evaluation of the extent to which their job abroad was/is related to the obtained speciality (study programme)

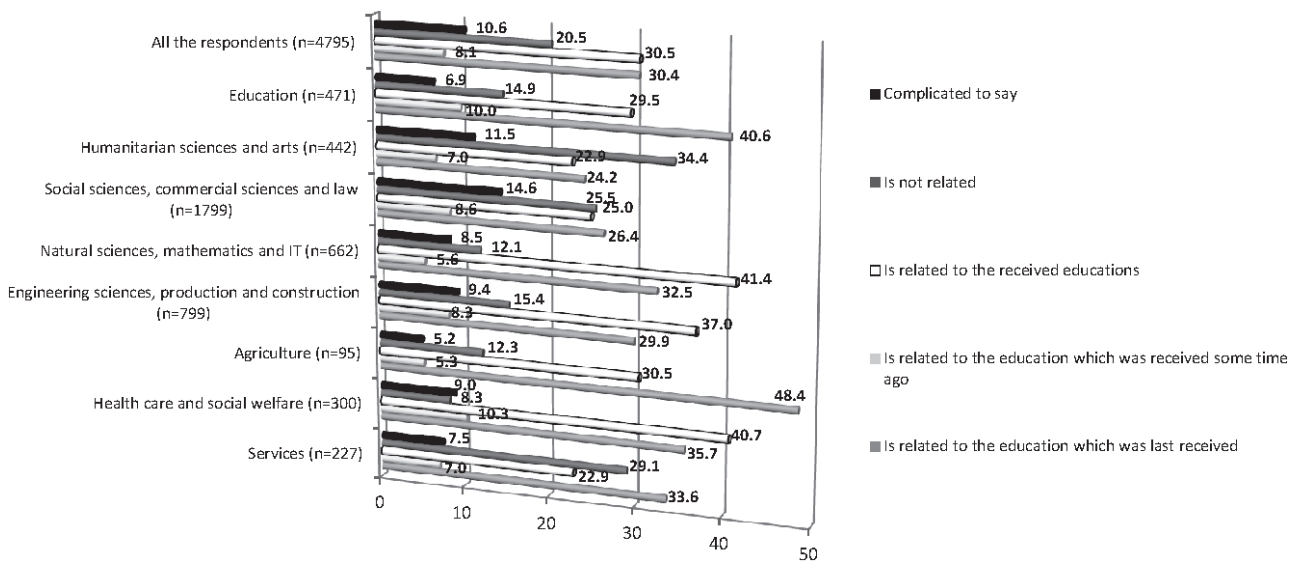

Figure 3. Graduates' evaluation of the extent to which their current job is related to the obtained speciality (study programme)

Figure 3 shows the following trend: the respondents having graduated from the thematic group of health care and social welfare, agriculture, education, natural sciences, mathematics and information technology $(80 \%-87 \%)$ are, to the greatest extent, involved in the jobs related to their field of studies. To the lowest extent, the respondents having graduated from the field of humanities and arts (54\%) or social sciences, commercial sciences and law $(60 \%)$ work in the job related to their studies.

Apart from calculations, there is a number of suggestions that universities' graduates have provided. These are provided in the next chapter. 


\section{Graduates' suggestions regarding the possibilities to gain better entrepreneurship education during their studies}

In order find out the possibilities for developing entrepreneurial abilities during the study process and to establish their own enterprise and in order to find out what the higher education institutions should do in this field, the respondents had to provide answers to two open questions: What are the necessary knowledge and skills for entrepreneurship to be learned and gained at university? and What should universities do for encouraging graduates' involvement in entrepreneurship?

Almost all the respondents have provided answers to these questions, even more the answers are exhaustive. Summarised, analysed and grouped commentaries of the respondents (in total 1.000 answers were evaluated), testify that most of the respondents suggestions are extended not only to development of entrepreneurial skills, but to the whole study process in general. Taking into account the large amount of suggestions, based on the frequency distribution, only the most important opinions are included in the paper.

Most of the respondents provide answers on the necessity to ensure much more competitive education in Latvian universities by improving the study process quality, improving the contents of study courses, teaching (learning) method and by changing the attitude of academic staff, by motivating students to develop their skills. In this context, they suggest implementing a new education system model by ensuring qualitative study process in accordance to the ongoing changes in society and labour market demands. Besides, it is suggested that universities develop study programmes in cooperation with employers to improve and renew the study programmes in accordance to the new trends of economy, to ensure positive environment for ideas generation that would promote self-initiative, courage, innovative thinking and increase interest as well as promote development abilities that would be useful in entrepreneurship. It is also important to involve the courses that are actual for today's situation and encourage students' interest for entrepreneurship in study programmes.

Some comments include: one should escape from using old study materials in lectures, escape from formal teaching; teaching staff should be interested in order to provide high quality of education. Study programmes at universities should be developed in order to raise entrepreneurs, employers, people who generate their business ideas, involve actual development trends and see the free niches, the successful scenarios in other world. As one of the respondents suggest: not all people should be entrepreneurs, yet the study course in entrepreneurship should be the compulsory course. Even in case the profession gained is not related to entrepreneurship, it should be taught at university at a sufficient level.

As regards improvement of study courses contents, many respondents stress the necessity to balance possibilities for learning theory and practice (by increasing the amount of contact hours in favour of practical seminars). The study programmes should be analysed and renewed constantly by providing courses with the newest trends and the most actual information. They suggest that, during the study course "Entrepreneurship", the students should elaborate a business plan, which is directly related to the faculty specifics, by showing how, for instance, a musician, a designer, a historian, a nature specialist, etc. could solve innovative ideas in entrepreneurship in relation to the study field. 
Others do suggest to involve a compulsory part of development of students' enterprise within the period of all four years in the study to allow students to be involved in all stages of enterprise development - from the beginning till production phase or phase for providing services - as it is important to gain real idea on the process of enterprise development and the activities performed in the frames of it. In case there are losses for the enterprise, the evaluation of students' knowledge is insufficient. Many people provide idea that both in professional and academic study programmes the elaboration of students practical works should be foreseen in accordance to the requests of economy. For several lectures and seminars, specialists of different spheres should be invited more often. One of the respondents wrote that all the study courses should foresee innovative solutions not from the perspective of employee, but from the perspective of employer. It is important to divide entrepreneurs (ready to take risk) and managers (not willing to take risk), and more attention should be paid to getting practical training: managers for training in management, entrepreneurs for training in entrepreneurship. During the whole study process, nobody even tried to encourage us as potential entrepreneurs or employers.

Many respondents stress the necessity to change attitude of the academic staff towards students, to motivate students to develop their skills in order to become highly qualified and competitive specialists. Graduates note the necessity not to break the backbone of the potential entrepreneurs by making students feeling scared. Creative thinking should be promoted, new ideas and skills should be evaluated positively and not righted in order for them not to be frightened to realise them. Universities should more provide practical knowledge, offer and stimulate starting of some kind of entrepreneurship. As one of the respondents note, in general, the task of the higher education institutions is to encourage, but, unfortunately, hindering and criticising appears more. There are also commentaries concerning the necessity to improve professional competence of academic personnel to ensure teaching of study courses with highly qualified, professional, progressively thinking academic staff members (holding experience both in practical work and in research). According to their opinions, the knowledge gained in higher education institutions is very theoretical, and a more practical approach is necessary in all spheres. Students should be provided with a possibility to act individually, to learn the real situation in entrepreneurship. Practical training is necessary as well. Cooperation with entrepreneurs should be developed in order to adjust study programmes to the requirements of labour market and to provide the necessary skills.

\section{Conclusions and suggestions}

Labour market challenges in the $21^{\text {st }}$ century, its quantitative and qualitative changes, and an increasing role of human capital nominate higher requests for education. Throughout the scope of internationalisation higher education itself has to be competitive, sustainable and qualitative. There are different definitions of these terms, inter alia different approaches on measuring higher education. Yet one of the components taken into account when evaluating education quality is the evaluation of the university graduates' opinions on their education quality and competitiveness. Besides, the EC policy planning documents state that the graduates should have skills in entrepreneurship, this component is more and more involved in quality surveys. 
For evaluating higher education quality in Latvia a survey of 4.909 graduates (20062011) representing six Latvian universities was performed from November 2011 to December 2011. The graduates both evaluated their education quality and provided suggestions for its improvement, inter alia concerning the possibilities to improve entrepreneurship education.

Survey results of university graduates (2011) indicate the most positive opinions on having gained theoretical knowledge, abilities to present information and to evaluate, analyse and systematise it. At the same time, the report found that too little attention is paid to the practical side of the study process: the possibility for students to work in projects and research in order for them to find solutions, to use information technologies, to develop the necessary skills that correspond to today's labour market requirements.

Previous research papers prove that the EC guidelines on the necessity to promote entrepreneurial skills for all the young people are not fully implemented in Latvia universities. There are a high number of students who haven't developed entrepreneurial skills during their studies. In case study courses are provided in context of entrepreneurship education, they are mainly oriented towards gaining theoretical knowledge. Entrepreneurial skills are developed at a low or very low level.

Findings of the research allow to conclude that, in general, the new specialists in Latvia universities are prepared in accordance with the present labour market challenges and are competitive in the Latvian labour market, but their competitiveness in the EU labour market a bit lower, yet more than half of the graduates from all the thematic groups evaluate their education to be competitive in the EU labour market.

It is necessary to review the regulations of the Cabinet of Ministers of the Republic of Latvia of November 20, 2001 (Latvijas Republikas Ministru kabinets [the Cabinet of Ministers of the Republic of Latvia], 2001) by foreseeing in them entrepreneurship education possibilities for all students and by integrating entrepreneurship development elements in different study courses in all study programmes and by introducing 12 credit points (18 ECTS) module instead of 6 credit points (9 ECTS) module in all study programmes, according to the faculty specifics.

In order to ensure competitive higher education and to increase its quality, it is important to introduce improvement system of academic personnel competencies in Latvia. Contents and quality of study courses should be changed substantially by involving more unification of theory and practice in study courses and by providing possibilities for students to study by doing in order to confirm their skills in concrete activities, by searching innovative approaches for solving economic problems.

\section{Acknowledgement}

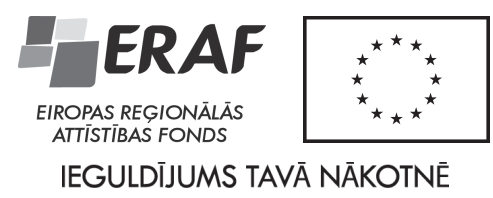

Elaboration of the scientific publication was possible due to the financial support of the European Regional Development Fund project No. 2010/0294/2DP/2.1.1.2.0/10/APIA/ VIAA/009 


\section{References:}

Acqui, E. (2012). Contributions to the development of the $21^{\text {st }}$ century higher education. Quality - access to success, 13(2), 50-55.

Adcroft, A., Teckman, J., \& Willis, R. (2010). Is higher education in the UK becoming more competitive? International Journal of Public Sector Management, 23(6), 578-588.

Augstāko un profesionālo mācību iestāžu absolventu profesionālà darbība pēc mācìbu beigšanas [Professional activities of graduates of higher and vocational education institutions after graduation]. (2007). Rīga: LU Akadēmiskais apgāds.

Bikse, V., \& Riemere, I. (2013). The development of entrepreneurial competences for students of mathematics and the science subjects: The Latvian experience. ProcediaSocial and Behavioral Sciences, 82, 511-519.

Bokhari, Z. A. (2010). Role of universities in market, product, and business development: An entrepreneurial macro approach for community development by adopting micro strategies. Retrieved November 13, 2012, from http:/www.mmaglobal.org/ publications/ProceedingsArchive/2010_FALL_MMA.pdf

Daun, H., \& Arjmand, R. (2005). Education in Europe and Muslim demands for competitive and moral education. International Review of Education, 51(5/6), 403-426.

Dawson, S., Burnett, B., \& O’Donohue, M. (2006). Learning communities: An untapped sustainable competitive advantage for higher education. International Journal of Educational Management, 20(2), 127-139.

Dobson, A., Quilley, S., \& Young, W. (2010). Sustainability as competitive advantage in higher education in the UK. International Journal of Environment \& Sustainable Development, 9(4), 330-348.

EC (European Commission). (2002). Final report of the expert group "Best procedure" project on education and training for entrepreneurship. Retrieved July 5, 2012, from http://europa.eu.int/comm/enterprise/entrepreneurship/support_measures/ training_education/index.htm

EC (European Commission). (2006). Entrepreneurship education in Europe: Fostering entrepreneurial mindsets through education and learning. Retrieved June 25, 2012, from http://ec.europa.eu/enterprise/entrepreneurship/support_measures/training education/index.htm

EC (European Commission). (2008). Entrepreneurship in higher education, especially in non-business studies. Retrieved April 4, 2012, from http://ec.europa.eu/enterprise/ entrepreneurship/support_measures/training_education/entr_highed.pdf

EC (European Commission). (2011). Supporting growth and jobs - an agenda for the modernisation of Europe's higher education systems. Retrieved April 18, 2012, from http://ec.europa.eu/education/higher-education/doc/wp0911_en.pdf

EC (European Commission). (2012a). Effects and impact of entrepreneurship programmes in higher education. Retrieved November 12, 2013, from http://ec.europa.eu/ education/news/rethinking/com669_en.pdf

EC (European Commission). (2012b). Rethinking education: Investing in skills for better socio-economic outcomes. Retrieved November 12, 2013, from http://ec.europa.eu/ education/news/rethinking/com669_en.pdf 
Fadeeva, Z., \& Galkute, L. (2012). Looking for synergies: Education for sustainable development and the Bologna process. Journal of Education for Sustainable Development, 6(1), 91-100.

Federkeil, G. (2008). Higher education in Europe. Rankings and quality assurance in higher education, 33(2/3), 219-231.

Gendjova, A., \& Kamusheva, A. (2012). Generic skills and competences for professional development of the Chemistry graduates of Sofia University. Chemistry, 21(2), 202-214.

Krivova, D., \& Myachin, Y. (2011). Conceptual basics of changes in the system of higher education in the frames of sustainable development paradigm of society (by the example of russian federation). Economics \& Management, 16, 785-788.

Latvijas Republikas Ministru kabinets [the Cabinet of Ministers of the Republic of Latvia]. (2001). Noteikumi par pirmāa, kā arī otrā lìmeņa profesionālās augstākās izglitîbas valsts standartu (2001. gada 20. novembra noteikumi Nr. 481) [on the state standard of the second level professional higher education; regulations No 481 of 20 November 2001]. Retrieved September 06, 2012, from http://www.mk. gov.lv/likumi

LUA (Latvijas Universitāšu asociācijas) projekts "Universitāšu ieguldīums Latvijas tautsaimniecīb $\bar{a}$ " [Project of universities investment in Latvian economy (UILE)]. (2012). Retrieved June 25, 2012, from http://www.lu.lv/fileadmin/user_upload/ lu_portal/par/strukturvienibas-un-infrastruktura/saist/lua/Universitasu_ieguldijums_ Latvijas_tautsaimnieciba.pdf

Poisson, R. (2012). How to foster the competitiveness of the European R \& D. III - the answer of the academic world. Actualite Chimique, 363, 13-17.

Qi, Y. (2011). Improving graduates' employment competitiveness: A practice in Peking University. Education for Information, 28, 101-113.

Viederyte, R. (2009). Globalization influence on competitive education and knowledge spreading activity. Economics \& Management, 14, 1032-1036.

Zernov, V. A. (2009). The competitive level of education as a condition necessary for the development of a competitive economy. Russian Education \& Society, 51(7), 73-85.

\section{Correspondence:}

Veronika Bikse, Dr. oec., Professor Emeritus, Researcher of the Management Science Institute, Liepāja University, 14 Lielā 14, Liepāja, LV-3401, Latvia. Tel.: +371 2652463; +37129152582. Email: vbikse@lu.lv 